Mészöly Miklós

Mészöly Miklós filmterve Tóth Jánosnak

https://doi.org/10.31176/apertura.2019.15.2.9 


\section{Mészöly Miklós}

\section{Mészöly Miklós filmterve Tóth Jánosnak}

Városkép (esetleg éppen Budapest?) - de csak háztetô-panorámán keresztül: a legkülönfélébb tetôk, romlók és újak, ódon stíl-házaké és moderneké, gyáraké, pályaudvaroké stb. - de mindez úgy, hogy ez a tetô-labirintus a maga különös és mindennapi életünkben elég kevéssé figyelemre méltatott tartozékaival együtt kerüljön lencse elé, dinamikus hangulati egységbe füzve. Tehát: kémények, cserépsíkok, bádogfelületek, kiszögellések, kéményseprô-pallók, esốcsatornák részletekre rámenô, szuggesztív felfedezése és bemutatása.

Aztán perspektivikusan: a tetôrengeteg és az ég.

Fény-árnyék hatások a tetốkön. Elborul az ég. Esni kezd. Az elôbb csak gyér, majd egyre szaporább esôcseppek játéka a különbözô tetôrészleteken.

Zuhogni kezd.

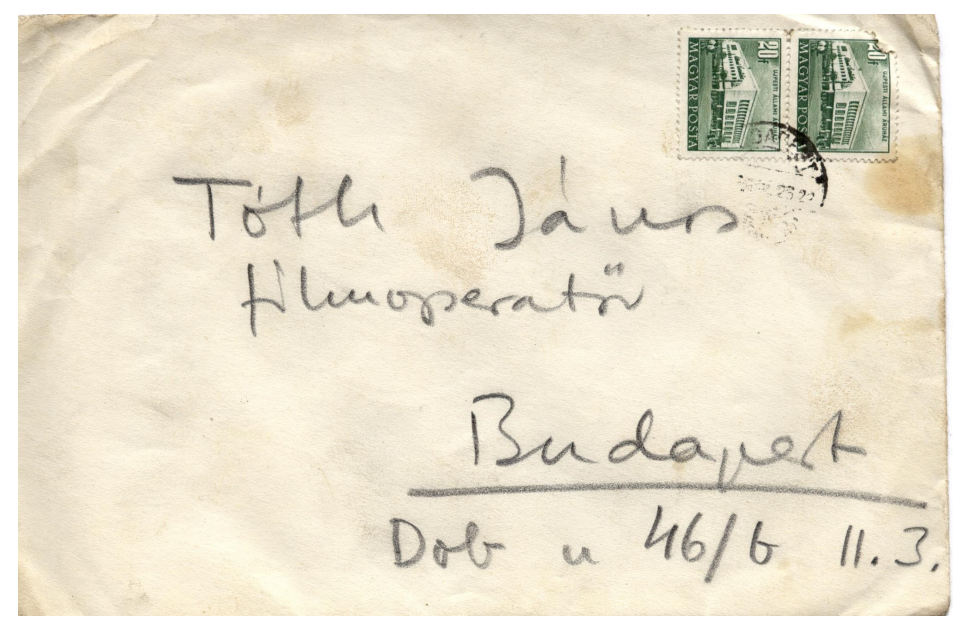

Mészöly Miklós levele

Ettôl kezdve a zuhogó, ömlő, spriccelô vizet mutatjuk be a tetôlabirintusnak már ismert, ill. váratlanul újszerú részletein keresztül. Egyszóval a víz festôii, szinte élôlényszerú útját lefelé, a legkülönbözóbb módokon és tárgyi elemekhez kapcsolódva. A képsornak mintegy összegezôje: az esốcsatornákban ömlô, ill. csatorna híján lecsurgó víz. (Itt is a csatornák vizuális változatosságára kell törekedni, ügyelve a hangulati egymásutánra, kontrasztra stb.)

A csatornák, ill. csurgások útját követve lassan távolodunk a tetôk világától, és közeledünk a föld felé. (Pl. csurgások estükben, a levegôben fotografálva, jól megválasztott pillanatokban, mikor valamilyen tárgyba ütközve „gellert” kap a víz; - aztán a nagy mélységet, ill. magasságot érzékeltetô beállítások, amikor a csatornákra közvetlen közelrôl lenézünk felülrôl, és felnézünk 
alulról; - a függóleges csatornák kicsapódó spricceléseinek játéka; - stb.)

Lent vagyunk a földön. A csatornák mind befúródnak a földbe. Vagy a járdára csurgatják a vizet. Ezt a mindennaposságot felfedezésszerúen mutatjuk be, gyors, ugyanezt a tényt ismétló és variáló képsorral.

Követjük a tovább ömló víz útját az úttestre, ahol az utcai csatornanyílások nyelik el. Ezeknek az úttesten áradó vízfolyásoknak spontán - s ismét élőlényszerú - formálódását, mozgását, fényárnyék játékát mutatjuk be.

Hangsúlyos érzékeltetése annak, hogy minden lezúduló víz a csatornanyílások felé törekszik.

S lemegyünk a víz után a föld alá. A város alatti vízelvezetô hálózatnak a világába kerülünk. Itt már a megcsendesedett, de szinte feketén hömpölygő víznek az útját követjük; a képsor sötét, drámai. A földalatti vízelvezetô hálózat tárgyi adottságain keresztül azt a mérnöki, s az emberi organizációt még ebben az „alvilági” szektorban is jellemzô céltudatosságot érzékeltetjük, ami a tetô-labirintus bemutatásánál inkább játékosságban, spontán esztétikumban, s a formák levegốsebb összhatásában nyilvánult meg. (A zene - ami az eddigiek során igen kifejezô része volt a filmnek - itt esetleg teljesen el is maradhatna: csak a képek sora s a feketén hömpölygő víz loccsanásai.)

Képsor világosodik. Közeledünk a csatornahálózat kivezetố nyílásaihoz. Hirtelen robbanó napfény. Ebben a világításban látjuk a különbözố szenny- és vízkivezetố csatornák nyílásait, amint árad ki rajtuk a piszkosan habzó víz. Mindezt több változatban, helyen és formában.

A képsor (s zene) innét kezdve egyre derúsebb: az olajos, hordalékos és szemetes, szinte szurkosan kiömlô víz egyre inkább oldódni és tisztulni kezd egy tágabb víztükör csillogó, játékos ezüstjén. Lassú, békés vízáramlás képével egy pillanatra becsapjuk a nézôt. Falevél, leveles ág sodródik a hullámokon.

Aztán a zene hirtelen vadabb, drámaibb ütemre vált át: két szélhajtott nagy felhőgomoly egymásba tûnését látjuk, mintha fehér habokká korbácsolt vízzuhatag látványa kísértene, költối elrajzolással.

Errốl a képrốl megyünk át az elôbb még csendesen hömpölygố vízre: a sodra most már egyre vadabb, tarajosabb (mint mikor egy kisebb fajta vízlépcsô meggyorsítja és meghabosítja a vizet), aztán követjük ennek a meggyorsult sodrásnak az útját, egészen addig, míg váratlanul szédítô mélységbe zúdulnak le a hullámok, s lent felhôs habzással szinte egy gomollyá állnak össze.

Távolodva - de a kép középpontjában ezt a gigantikus habzást hagyva meg: - mind magasabbról, felülrôl fotografáljuk egy fokról-fokra kibontakozó, hatalmas vízierômú lezúduló vizét. 

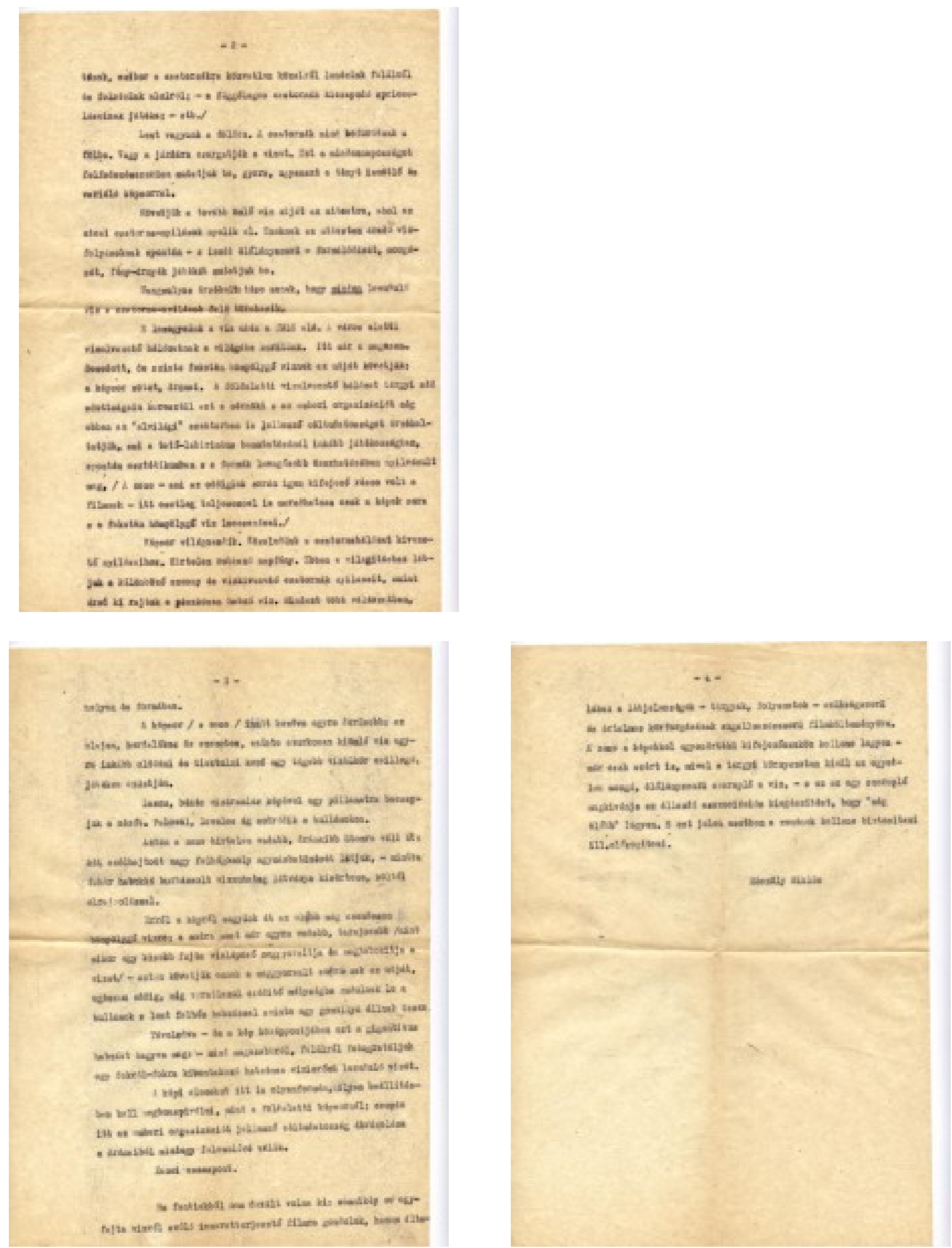

Mészöly Miklós levele Tóth Jánosnak

A képi elemeket itt is olyanformán, olyan beállításban kell megkonspirálni, mint a földalatti képsornál; csupán itt az emberi organizációit jellemzố céltudatosság ábrázolása a drámaiból 
mintegy felemelóvé válik.

Zenei csúcspont.

Ha fentiekból nem derült volna ki: semmiképp se egyfajta vízrôl szóló ismeretterjesztô filmre gondolok, hanem általában a létjelenségek - tárgyak, folyamatok - szükségszerú és értelmes körforgásának sugalmazás-szerú filmkölteményére. A zene a képekkel egyenértékú kifejezôeszköz kellene legyen - már csak azért is, mivel a tárgyi környezeten kívül az egyetlen mozgó, élőlényszerú szereplô a víz - s ez az egy szereplô megkívánja az állandó asszociációs kiegészítést, hogy „még élôbb” legyen. S ezt jelen esetben a zenének kellene biztosítani, ill. elôsegíteni. 
(C) Apertúra, 2020. tél | www.apertura.hu

webcím: https://www.apertura.hu/2020/tel/meszoly-miklos-filmterve-toth-janosnak/

https://doi.org/10.31176/apertura.2019.15.2.9

$$
\text { (2) opertúro }
$$

